\title{
An update on the genus Parmelinella Elix \& Hale (Parmeliaceae, lichenized Ascomycetes)
}

\author{
Benatti MN ${ }^{1}$ \\ ${ }^{1}$ Instituto de Botânica, Núcleo de Pesquisa em Micologia, Caixa Postal 68041, São Paulo / SP, CEP 04045-972, \\ Brazil.E-mail:michel_benatti@yahoo.com.br
}

Benatti MN 2014 - An update on the genus Parmelinella Elix \& Hale (Parmeliaceae, lichenized ascomycetes). Mycosphere 5(6), 770-789, Doi 10.5943/mycosphere/5/6/8

\begin{abstract}
A detailed morphological and anatomical investigation of the type specimens of the currently accepted species of Parmelinella (Parmeliaceae, Lichenized Fungi) confirmed the current species delimitations and revealed additional characteristics. The name Parmelia mutata is removed from synonymy with Parmelinella versiformis and proposed as a new combination, and Parmelia nimandairana is removed from Parmelinella wallichiana and proposed as another new combination. Parmelinella salacinifera is proposed as a new combination. A lectotype is designated for Parmelinella versiformis. A key to all currently accepted species of the genus is presented.
\end{abstract}

Key words - Canoparmelia - Parmelina - Parmotremopsis - cilia - salazinic acid

\section{Introduction}

Elix \& Hale (1987) installed the genus Parmelinella for three species previously included in Parmelina ( $P$. wallichiana, $P$. manipurensis and $P$. simplicior) with broad, rotund lobes, an emaculate thallus, sparse, simple cilia more or less restricted to the axils, simple black rhizines, ellipsoid ascospores, short cylindrical conidia, and salazinic and consalazinic acids in the medulla. A key for the differentiation of this and some further newly proposed genera, all segregates of Parmelina, and a table containing many characteristics for them was included with the descriptions of the genera. For the pertinent species only the new combinations were given, no keys or comments.

Parmelinella wallichiana (Taylor) Elix \& Hale was assigned as type species. The most closely related genus was also described in this paper: Parmotremopsis Elix \& Hale, differentiated by smaller ascospores and conidia (with near half the size of those of Parmelinella species) and by the presence of norstictic acid in the medulla. Due to subsequent discoveries, the originally proposed differences in ascospore size of Parmelinella and Parmotremopsis species are significantly reduced, and the conidia size and the medullary chemistry remain as principal discriminators.

As discussed in Benatti (2012a, 2013), several Bulbothrix species containing salazinic acid are also possibly related to Parmelinella making the genus paraphyletic (Crespo et al. 2010). Recent molecular research (Divakar et al. 2006, Crespo et al. 2010) points out that several Bulbothrix species containing medullary salazinic acid may actually belong to Parmelinella, or even possibly comprise a small genus that is closely related to it. 
The genus contains three species transferred from the genus Parmelia: P. wallichiana (Taylor 1847), P. versiformis (Krempelhuber 1878) and P. cinerascens (Lynge 1914), while another four species have been described in the last 25 years.

This work aims to update the published information on the species of Parmelinella, presenting several interesting features for their identification and relationship and a key for their identification as well as treating several possibly related or easily confused species.

\section{Materials \& Methods}

Type material and several additional specimens were studied from ASSAM, B, BM, FH, FLAS, G, M, NY, S, SP, TNS, US, and UPS, originating from Asia, Africa, and South America.

The methodology and conventions are detailed in Benatti (2012a), except that no species treated here has bulbate cilia. The chemical constituents of all specimens examined were identified by thin-layer chromatography (TLC) by several researchers, as there are often several labels (including those of Mason E. Hale), and depict cortical atranorin and medullary salazinic acid for most species, while a few specimens had their substances determined by high performance liquid chromatography HPLC by John A. Elix, also on labels with the specimens. Thus it was not necessary to repeat any chemical analyses, which would be problematic due several materials being small thalli, often showing hydrolysis and oxidation of the salazinic acid.

The presence of salazinic acid, an apparently widespread substance in the genus, is easily detected by a $\mathrm{K}+$ yellow $\rightarrow$ dark red spot test reaction. As explained in Benatti (2012a), its presence could sometimes be perceived by the formation of bundles of thin, elongated crystals with a deep reddish colour, observed under light microscope after the transfer of hyphae onto a microscope slide and adding the reagent, cutting a small piece of the thallus or of the apothecia. However, unlike norstictic acid, salazinic acid crystals require higher concentrations of this substance and take longer to crystallize.

\section{Results}

With the exception of Parmelinella cinerascens, $P$. nimandairana, $P$. salacinifera and $P$. wallichiana which are isidiate, the other five species lack vegetative propagules (species with pustules or soredia are unknown). All species are predominantly corticolous. However, $P$. chozoubae and $P$. cinerascens can be predominantly or rarely be found saxicolous. Parmelinella manipurensis is mentioned in literature as a saxicolous species, but unfortunately no specimens of this species could be located, including the type specimens recorded as being lodged in CAL and US.

\section{Parmelinella Elix \& Hale}

Mycotaxon 29: 233. 1987.

Type species - Parmelinella wallichiana (Taylor) Elix \& Hale. Mycotaxon 29: 233. 1987.

Thallus foliose, corticolous or saxicolous, coriaceous to submembranaceous, adnate, lobes irregular to \pm sublinear, 1-15 mm wide, apices \pm rotund, margins smooth to crenate, sparsely ciliate, cilia sparse at the margins, commonly appearing in the axils, simple, slender, up to $0.6 \mathrm{~mm}$ long. Upper surface grey to yellowish or greenish gray, maculae and pseudocyphellae absent, with a perforate polysaccharide covering. Underside black to brown or variable at center, rhizinae usually simple, occasionally furcate or irregularly branched, sparse to dense, margins usually brown, distinct, naked or papillate, sometimes also black like the center. Isidia present or absent. Soredia and phyllidia unknown. Apothecia adnate to sessile, disc imperforate, ascospores globose to ellipsoidal, simple, 8 per ascus, 5-28 $\times 4-16 \mu \mathrm{m}$, epispore 1-4 $\mu \mathrm{m}$. Pycnidia black, laminal, immersed, conidia cylindrical, bacilliform or weakly bifusiform, 5-9 $\mu \mathrm{m}$ long.

Upper cortex containing atranorin, with some species producing variable amounts of chloroatranorin and secalonic acid A. Medulla white to sometimes partially pale yellowish, containing salazinic and consalazinic acids, some species also containing pigmentosin $\mathrm{A}$ and eumitrin derivates. 


\section{Key to the species of Parmelinella}

1. Thallus isidiate

2. Lobes 3-15 mm wide, lower cortex variably brown to black; ascospores $15-20 \times 10-12.5 \mu \mathrm{m} \ldots$. P. wallichiana

2. Lobes 1-4 mm wide; lower cortex brown throughout or black with brown margins

3. Lower cortex brown; sparse marginal and axillary cilia absent or rare P. salacinifera

3. Lower cortex black; marginal and axillary cilia always present

4. Cilia scarce at lobe axils; rhizines simple; ascospores 8-12 $\times 4-6 \mu \mathrm{m}$

P. cinerascens

4. Cilia scarce to dense at lobe axils; rhizines simple to dichotomously branched; ascospores $14-18 \times 8-10 \mu \mathrm{m}$

P. nimandairana

1. Thallus not isidiate

4. Cilia often with thick (but not bulbate) bases; lower surface entirely or almost entirely black; rhizines simple to furcate or irregularly branched P. chozoubae

4. Cilia with thin bases; lower surface entirely black, with distinct brown margins or entirely brown; rhizines only simple

5. Ascospores 15-29 $\times 10-17 \mu \mathrm{m}$; episporium 1-3 $\mu \mathrm{m}$ thick; lower surface brown or black

6. Lower side dark to pale brown; rhizines brown, simple .......................... P. versiformis

6. Lower side black, rarely with brown margins; rhizines black, simple to irregularly branched

P. mutata

5. Ascospores 8-17 $\times 7-10 \mu \mathrm{m}$, episporium ca. $1 \mu \mathrm{m}$ thick; lower surface black, margins black or brown

7. Thallus corticolous; laciniae 1-5.5 mm wide P. simplicior

7. Thallus commonly saxicolous; laciniae 6-12 mm wide P. manipurensis

Parmelinella chozoubae (Singh \& Sinha) Elix \& Pooprang. Mycotaxon 71: 121. $1999 . \quad$ Figs 1-3 MycoBank 808961

Basionym - Parmelia chozoubae Singh \& Sinha. Nordic Journal of Botany 13: 463. 1993.

Holotype - India, Nagaland State, Phek dist., near Chozouba, Chakhalama-Zunheboto Road, alt. ca. 1575 m, leg. K. P. Singh \& G. P. Sinha 2260, 7-IX-1986 (ASSAM!, isotype US n.v.).

Thallus sublinearly laciniate to wide laciniate, pale greenish gray in the herbarium, fragments up to $7.6 \mathrm{~cm}$ diam., coriaceous, saxicolous or corticolous. Laciniae anisotomic dichotomously branched, $0.7-2.5(-3.8) \mathrm{mm}$ wide, contiguous to imbricate becoming crowded at the center, adnate, adpressed, with flat to slightly involute, truncate to subtruncate apices, margins flat, smooth to crenate or subirregular, entire to incised, often sublacinulate, axils oval or irregular. Upper surface smooth eventually becoming rugose in older parts, mostly continuous, with few fissured parts. Adventitious lobules eventually spreading from lobe margins on older parts, 0.1-1.6 $\times 0.1-0.7 \mathrm{~mm}$, common, simple or irregularly branched, plane, truncate to subtruncate, partially ciliate, underside concolorous with the lower marginal zone. Maculae absent. Cilia black, apices simple to occasionally furcate, $0.05-0.50 \times$ ca. $0.03-0.05 \mathrm{~mm}$, usually common at the lobes axils and crenae, sparse at other parts. Soredia, isidia and pustules absent. Medulla white, without pigments. Lower surface almost entirely black, shiny, smooth to rugose, papillate, densely rhizinate. Marginal zone black indistinct from the center to dark brown in part and attenuate, up to $1.0 \mathrm{~mm}$ wide, shiny, smooth to rugose, papillate. Rhizines black, simple to furcate or sometimes irregularly branched, 0.10-0.40 (-0.60) × 0.03-0.05 mm, abundant, sometimes agglutinated, evenly distributed. Apothecia common, concave, sessile to adnate, margin smooth to subrugose and crenate, eciliate, amphithecium smooth to subrugose, $0.3-7.5 \mathrm{~mm}$ wide, often fissured and folded when mature; disc light brown, imperforate, epruinose; ascospores ellipsoid, (10.0-) 12.0-16.0 $\times$ 8.0-10.0 (-12.0) $\mu \mathrm{m}$, epispore 0.5-1.0. $\mu \mathrm{m}$. Pycnidia laminal to submarginal, common, immersed, with black ostioles, conidia weakly bifusiform, 5.0-6.0 $\times$ ca. $0.5 \mu \mathrm{m}$. 
Spot tests - upper cortex $\mathrm{K}+$ yellow, $\mathrm{UV}-$; medulla $\mathrm{K}+$ yellow $\rightarrow$ dark red, $\mathrm{C}-, \mathrm{KC}-, \mathrm{P}+$ yellow, UV-. Substances present: atranorin (major), salazinic acid (major), consalazinic acid (minor), norstictic acid (trace), secalonic acid A (trace). (TLC solvent C and HPLC, according to a label from John A. Elix left with the type material, 18-IV-2003).

Known distribution - Asia: China (Chen et al. 2003), India (Singh \& Sinha 1993, Divakar \& Upreti 2005, Divakar et al. 2000), and Thailand (Pooprang et al. 1999).

Notes - Singh \& Sinha (1993) mentioned that $P$. chozoubae could be found on rocks as well as the base of tree trunks (the type is corticolous, even if a saxicolous habit is reported to be most common). Although they were not reported, the type does have a few pycnidia with conidia, which are described here for the first time. P. chozoubae is known only for China, India and Thailand.

Chen et al. (2003) comment that $P$. chozoubae resembles $P$. simplicior in many aspects, except for the rhizine morphology and ascospore size. The authors gave a short description emphasizing the different aspects of $P$. chozoubae and $P$. simplicior. However, there were no comments about the marginal zone and the frequency and distribution of rhizines.

Divakar et al. (2000) described $P$. chozoubae with dense rhizines to the margin, and a uniformly black lower surface. By contrast, they reported that $P$. simplicior had sparse rhizines and brown colored lower cortex. However, Divakar \& Upreti (2005) later described Indian specimens of $P$. simplicior with a black lower surface, a naked or papillate brown margin, and sparse simple rhizines as the main differences.

Singh (pers. com.) informed me that he and G.P. Sinha described and published P. chozoubae based on an identification of M.E. Hale. Later, Elix received the specimen on loan, and thought that there were sparse bulbate cilia in the lobe axils and suspected it to be Bulbothrix meizospora (Nyl.) Hale. The species was thus reported as a synonym of B. meizospora by Singh \& Sinha (2010). However, after carefully examining the type and using the clarification methodology (Benatti 2011) to check for true bulbate cilia, I confirmed that the cilia were not bulbate, although some had enlarged bases (see figs. 2-3).

With this, I confirmed and accepted Parmelinella chozoubae as a valid species which was not synonymous with Bulbothrix meizospora (Benatti 2013).

It was difficult to find conidia in the type specimen, as many pycnidia were empty. The thallus is somewhat similar to those of Bulbothrix species containing norstictic or salazinic acids, but is more deeply laciniate than those of B. meizospora (Benatti 2013). The cilia in Parmelinella chozoubae are usually axillary, mostly simple to occasionally furcate, but never truly bulbate as those of B. meizospora.

Parmelinella cinerascens (Lynge) Benatti \& Marcelli. Opuscula Philolichenum 12: 27. 2012. Mycobank 563647

Basyonym - Parmelia cinerascens Lynge. Arkiv för Botanik 13: 104. 1914.

Holotype - Paraguay, Paraguari, ad arborem sat solitariam, in ripa rivuli campi, leg. G. O. Malme 1498, 02-VIII-1893 (S!).

Epitype (Benatti 2012): Brazil, São Paulo State, Ubatuba Municipality, Parque Estadual da

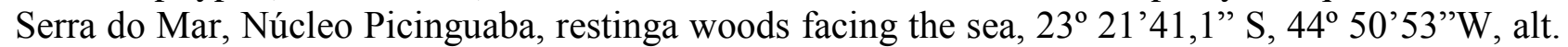
1 m., leg. A.A. Spielmann, P. Jungbluth, L.S. Canêz \& M.J. Kitaura 3155, 13-I-2007 (SP!, duplicate at $S$ !).

$\equiv$ Pseudoparmelia cinerascens (Lynge) Hale. Phytologia 29: 189. 1974.

$\equiv$ Parmelinella cinerascens (Lynge) Benatti \& Marcelli. Opuscula Philolichenum 11: 27. 2012.

$\equiv$ Canoparmelia cinerascens (Lynge) Elix \& Hale. Mycotaxon 27: 278. 1986.

$=$ ? Parmelia tiliacea var. eximia Steiner (G! lectotype). Jahres-Bericht der Schlesischen Gesellschaft für vaterländische Cultur: 138. 1888 (Tanzania, Usambara, leg. Meyer s.n.).

For description, comments and illustrations, see Benatti 2012b. 

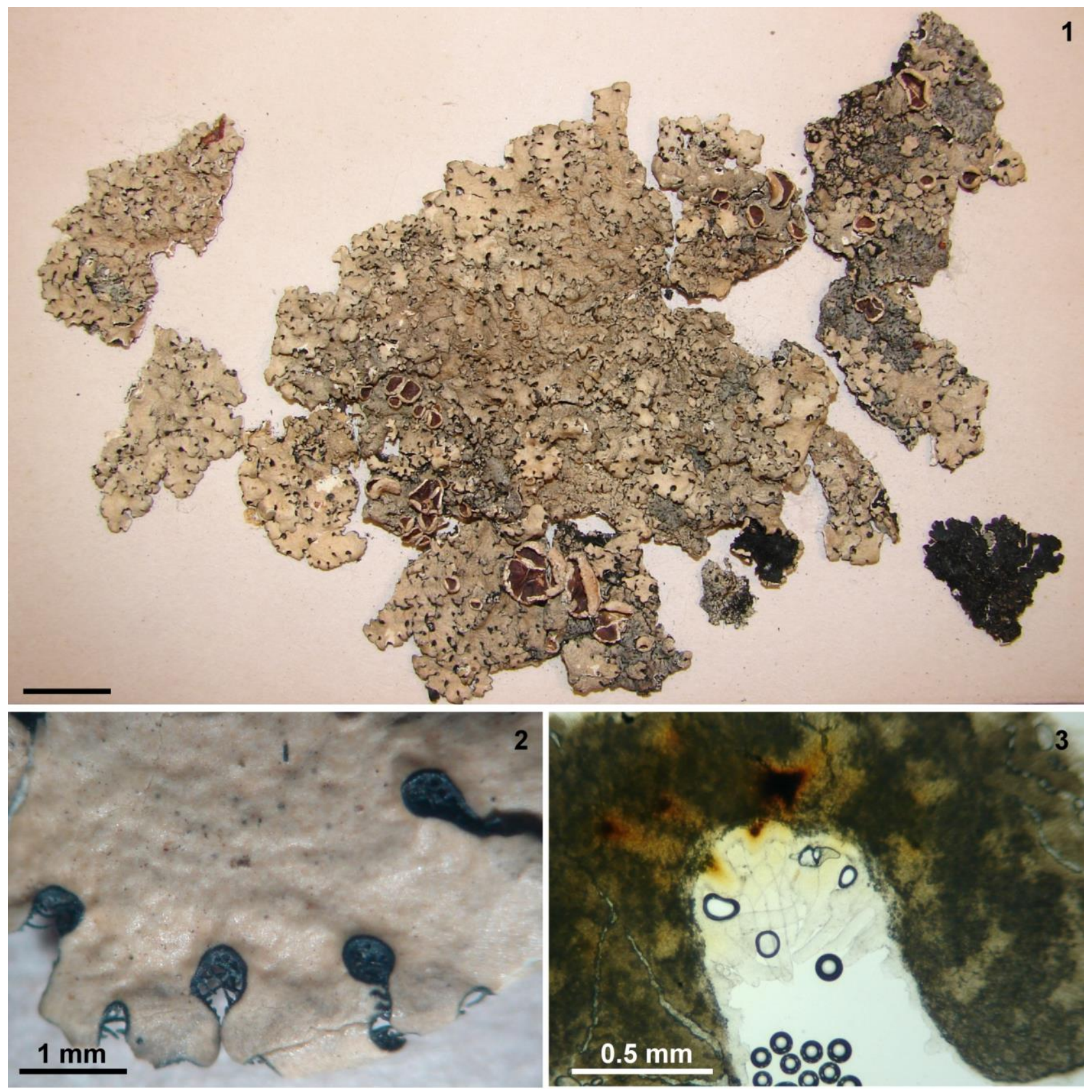

Figs 1-3 - Parmelinella chozoubae (ASSAM) 1 Holotype. 2 Detail of the axillary cilia. 3 Detail of the axillary cilia after clarification, showing abscence of bulbs. - Bars $=1 \mathrm{~cm} \mathrm{(1),} 1 \mathrm{~mm}(2), 0.5$ $\mathrm{mm}(3)$.

Additional notes- Xanthoparmelia murina (Kurok.) Elix could be confused with Parmelinella cinerascens. After examining the holotype (TNS!, figs 4-6), Xanthoparmelia murina differs by being apparently a strictly saxicolous species (restricted to eastern Australia and New Zealand) that is more laciniate than lobate, and instead of having short, axillary cilia, has a thick, eciliate marginal black line in the axils, formed by a thickening of the lower cortex, which is absent on Parmelinella cinerascens specimens (see Benatti 2012).

It is difficult to picture the thick marginal black line on Xanthoparmelia murina due it being small, the laciniae being narrow and often somewhat convex, turning down (figs. 5-6). Unlike the short cilia on Parmelinella cinerascens, which appear all over the thallus after a certain stage of development, the thickened black margin in the axils on $X$. murina is usually distinct only in the better developed, older parts. 
Accordingly to labels left with the holotype of Xanthoparmelia murina, Kurokawa originally thought that this species could be a synonym of Parmelinella cinerascens. The differences reported by Kurokawa (1985) did not clearly distinguish the two species, as there is some overlap relating to lobe width and aspect, upper cortical color, hymenium, asci and ascospores sizes. The consistent morphological differences are that $X$. murina (which also contains cortical atranorin) completely lacks marginal cilia, has more dense rhizines, a sublinear laciniate and lacinulate thallus, and a saxicolous to occasionally terricolous habit. Elix et al. (1986) and Elix (2003) confirmed that this species contains Xanthoparmelia-type lichenan in the cell walls explaining why Parmelia murina was combined into Paraparmelia and latter transferred to Xanthoparmelia.

Accordingly to Elix et al. (1986) and Elix (2003), X. murina occurs in arid to sub-arid areas of Australia, New Zealand and South Africa whereas Parmelinella cinerascens is common in less dry to more humid tropical locations in South America. No species of Xanthoparmelia is known to produce marginal cilia (Elix et al. 1986, Nash et al. 1995).

The type material of Parmelia tiliacea var. eximia (G!) is similar to P. cinerascens (Benatti 2011), and possibly not synonymous with $P$. wallichiana as suggested by Hale (1976). However, the apothecia are very numerous but immature $(\leq 1 \mathrm{~mm}$ wide). Some of the apothecia have marginal isidia. The hymenia is very poorly developed and does not appear to contain asci, which makes impossible to ascertain ascospores characteristics and confirm the status of this taxon. The type specimen has some partially pruinose lobes, while others are epruinose, often side by side. Because of the partially branched isidia, this African material could even represent a distinct taxon. Further collections are needed to clarify this problem.

The type material of Parmelia junodi (G!) contains a mixture of either Parmelinopsis minarum or $P$. horrescens (which better correspond to the protologue) and a fragment of what seems to be Parmelinella cinerascens (possibly explain why Hale thought that this may be synonymous with Parmelinella wallichiana). The material is damaged, the salazinic acid hydrolyzed so that it is difficult to examine the upper cortex to check for maculae.

Parmelinella mutata (Vainio) Benatti, comb. nov.

Figs $7-8$ Mycobank MB810422

Basionym - Parmelia mutata Vainio. Acta Societatis pro Fauna et Flora Fennica 7: 39. 1890.

Lectotype - Brazil, Minas Gerais, Sitio, Vainio Lichenes Brasiliensis Exsiccati 539 (TUR!; BM n.v., FH n.v., UPS! isolectotypes).

= Parmelia catharinensis Müller Argoviensis. Flora 74: 239. 1891. Type: Brazil, Santa Catarina, Blumenau, near Santa Catarina Island, leg. Ule 1891 (G!, lectotype, G!, W!, isolectotypes)

$=$ Parmelia wettsteinii Zahlbruckner. Denkschriften der Kaiserlichen Akademie der Wissenschaften, Mathematisch-Naturwissenschaftliche Classe. 83: 173. 1909. Type: Brazil, São Paulo, near Taipas, leg. Schiffner and Wettstein (W! lectotype, G n.v., isolectotype).

Thallus lobate, (pale) dusky gray in herbarium, fragments up to $7.2 \mathrm{~cm}$ diam., submembranaceous, corticolous. Lobes irregularly branched, 1.0-4.2 (-5.3) mm wide, imbricate to crowded, adnate, adpressed, with flat to slightly involute, rotund to subrotund apices, margins flat to slightly involute, subcrenate to crenate or subirregular, entire to incised, not lacinulate, axils oval to irregular. Upper surface subrugose to rugose with some irregular cracks mostly at older parts. Lobules or lacinulae absent, including marginal adventitious ones. Maculae absent. Cilia black, apices simple, $0.05-0.20 \times$ ca. $0.03(-0.05) \mathrm{mm}$, usually sparse in the lobes axils and other random areas. Soredia, pustules and isidia absent. Medulla entirely white, without pigmented spots. Lower surface almost entirely black, rarely with some dark brown patches, shiny, rugose or venate, papillate, moderately rhizinate, with some random bare areas. Marginal zone black or rarely dark brown, almost indistinct from the center to slightly attenuate, $0.5-2.0 \mathrm{~mm}$ wide, shiny, smooth to rugose or rarely venate, rhizinate. Rhizines black or occasionally dark brown, simple or rarely irregularly branched, $0.10-0.60 \times 0.03-0.05 \mathrm{~mm}$, frequent, evenly distributed. Apothecia common, concave, substipitate, margin smooth to subrugose, rugose, veined or crenate, eventually fissuring 

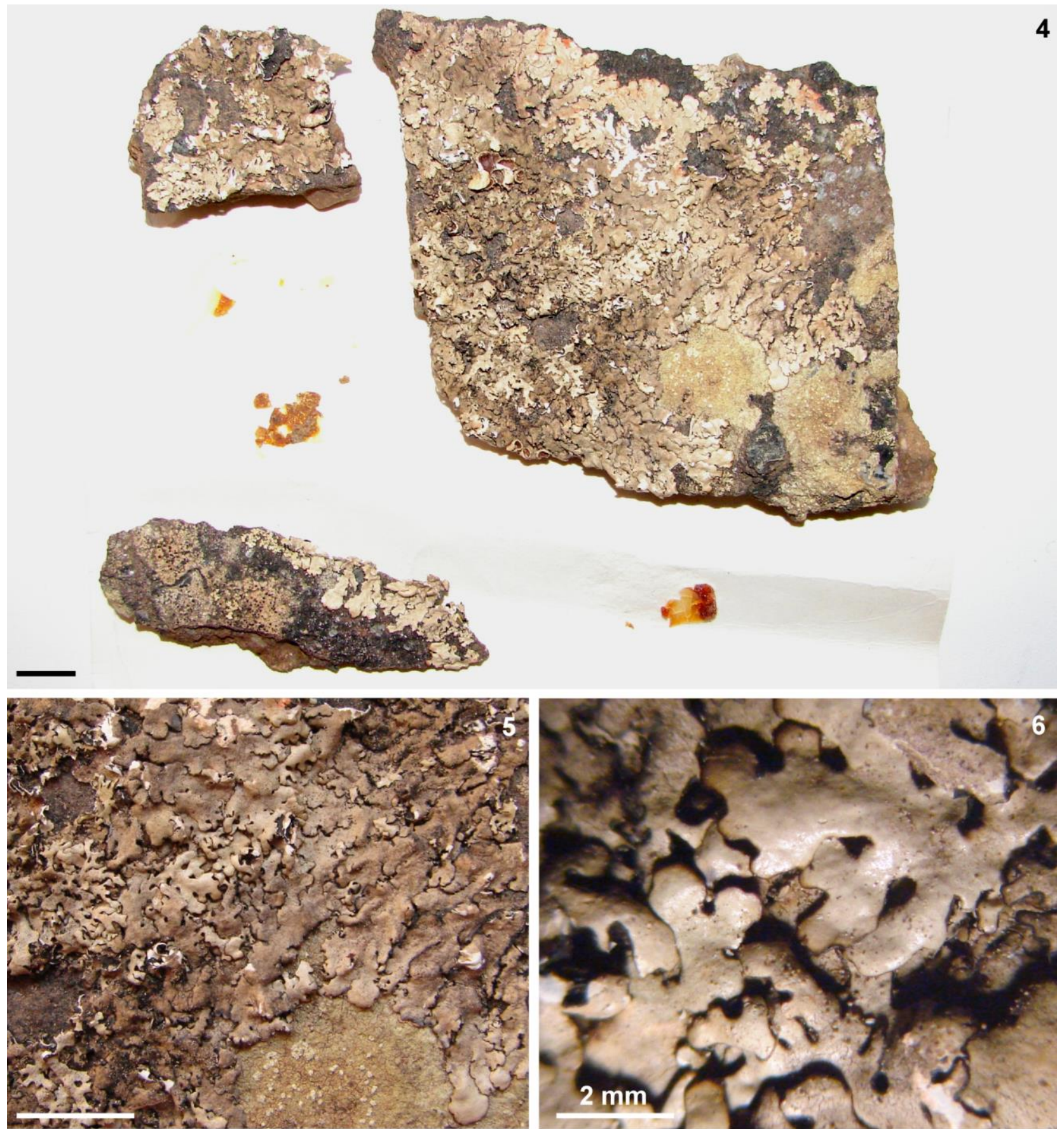

Figs 4-6 - Xanthoparmelia murina (TNS). 4 Holotype. 5 Detail of the laciniae aspect. 6 Detail of the axils, with total abscence of cilia. - Bars $=1 \mathrm{~cm}(4,5), 2 \mathrm{~mm}(6)$.

and folding when old, eciliate, amphithecium smooth to rugose, 0.3-6.3 (-12.5) $\mathrm{mm}$ wide; disc pale brown to brown, imperforate, epruinose; ascospores ellipsoid or oval, rarely subrotund, (12.0-) 15.0-29.0 × (8.0-) 10.0-16.0 $\mu \mathrm{m}$, epispore 1.0-2.5 $\mu \mathrm{m}$. Pycnidia sparse to common, immersed, with black ostioles, conidia (often absent) weakly bifusiform, (4.0-) 5.0-6.0 $\times 0.5 \mu \mathrm{m}$.

Spot tests - upper cortex $\mathrm{K}+$ yellow, UV-; medulla $\mathrm{K}+$ yellow $\rightarrow$ bright red, $\mathrm{C}-, \mathrm{KC}-, \mathrm{P}+$ yellow, UV-. Substances present: cortical atranorin, medullary salazinic acid (see also Hale 1976, and agreeing with labels on the lectotype and additional specimens examined).

Additional material examined - Brazil, Rio de Janeiro, leg. A. Glaziou 1822, 1823 (M). Idem, "Brasilia, Ypiranga, in horto botanico", leg. Luederwaldt 7391 (S). 
Known distribution - South America. Brazil, Minas Gerais, Rio de Janeiro, Santa Catarina and São Paulo (Müller Argoviensis 1891, Vainio 1890, Zahlbruckner 1909, including the synonyms $P$. catharinensis and $P$. wettsteinii).

Notes - Pamelinella mutata usually has a completely black lower cortex (even the marginal zone), large ascospores (mostly $\geq 20 \mu \mathrm{m}$ ), and sparse, very short cilia. Rather than being a synonym of $P$. versiformis, it is a similar species and to $P$. simplicior. $P$ versiformis has a (often pale) brown lower cortex, as seen in the type specimen. Both the lectotype (TUR-V) and the isolectotype (UPS) of $P$. mutata are small fragments a few centimeters wide, both somewhat damaged (the isotype lacking some distal parts), with several apothecia and many pycnidia. On intact lobes the lower marginal zone is entirely black, like the central parts.

Among the differences cited with the protologue, Vainio (1890) mentioned the broader lobes (3-10 $\mathrm{mm}$ wide), the absence of cilia, and a naked, brown lower marginal zone. However, the ellipsoid ascospores 15-22 $\times 8-14 \mu \mathrm{m}$, and sub-bifusiform conidia $5 \times 0.5 \mu \mathrm{m}$ he described are as observed. Authentic thalli of P. mutata actually have very sparse, short cilia, much like other species in the genus.

Parmelia catharinesis (G!) seems to be synonymous with $P$. mutata, rather than $P$. versiformis. It is composed of three fragments in good condition. Most lobes are less than $2.5 \mathrm{~mm}$ wide, but several marginal parts are missing. The apothecia are mature and often fissured and folded. Pycnidia are quite sparse and no conidia were found. This specimen has a completely black lower cortex. The cilia are hard to find, but are present. Müller Argoviensis (1891) description of Parmelia catharinensis mentions irregularly dichotomously branched lobes, an almost entirely black lower cortex, and ascospores $23-28 \times 12-14 \mu \mathrm{m}$ - very similar to $P$. mutata.

The isolectotype of Parmelia catharinesis in W consists of 3 somewhat damaged fragments, with apothecia $1.5-2.5 \mathrm{~cm}$ wide. There are no pycnidia present, and the margins are damaged or absent, leaving few intact lobes, but the simple, sparse, short cilia can be observed. The other isolectotype (G!) of Parmelia catharinensis is a well preserved material on thin twigs, with many, well developed apothecia containing mature ascospores and many pycnidia (although conidia were not found). The axillary cilia are difficult to see because of the distorted thallus with the margins folded towards the substrate, but are present. The lower cortex is almost entirely black, only a few parts of the marginal zone are dark brown.

The lectotype of $P$. wettsteini (W!) is partially burned. It is a small thallus with very sparse cilia totally restricted to the axils. Among differences from what was observed here, Zahlbruckner (1909) described a membranaceous thallus, larger lobes (17-20 mm wide), eciliate margins, a brown to dark brown lower cortex with naked margin, dense, simple rhizines, initially cupuliform, substipiate apothecia that become flat, and oval to ellipsoid ascospores $20-27 \times 12-16 \mu \mathrm{m}$ with a 1.6-1.8 thick epispore.

Ascospores sizes of the type and additional specimens appear to have a range variation: some specimens can have 15-25 $\mu \mathrm{m}$ long ascospores, others 24-29 $\mu \mathrm{m}$ long (giving at first the impression of more than one taxa involved), while others can be $16-28 \mu \mathrm{m}$ long, for example. No morphological feature varies enough to hint a possible involvement of two taxa, as first suspected.

Regarding a similar case with another group, as seen with some Bulbothrix species with medullary salazinic acid (Benatti 2012a, 2013), which are molecularly close to Parmelinella species (Crespo et al 2010), there is too a somewhat loose ascospore range and the specimens of a species (e.g., B. meizospora) may have ascospores of any length inside it. The ascospore sizes appears to be even more variable than those found on $P$. versiformis.

Parmelinella nimandairana (Zahlbruckner) Benatti \& Marcelli, comb. nov.

Figs 9-12 Mycobank MB810487

Basyonym: Parmelia nimandairana Zahlbruckner. Feddes Repertorium Specierum Novarum Regni Vegetabilis 33: 55. 1934.

Lectotype (as in Hale 1976): Taiwan, Nimandaira, Mt. Arisan, leg. Asahina 63. (W! isolectotype TNS!). 

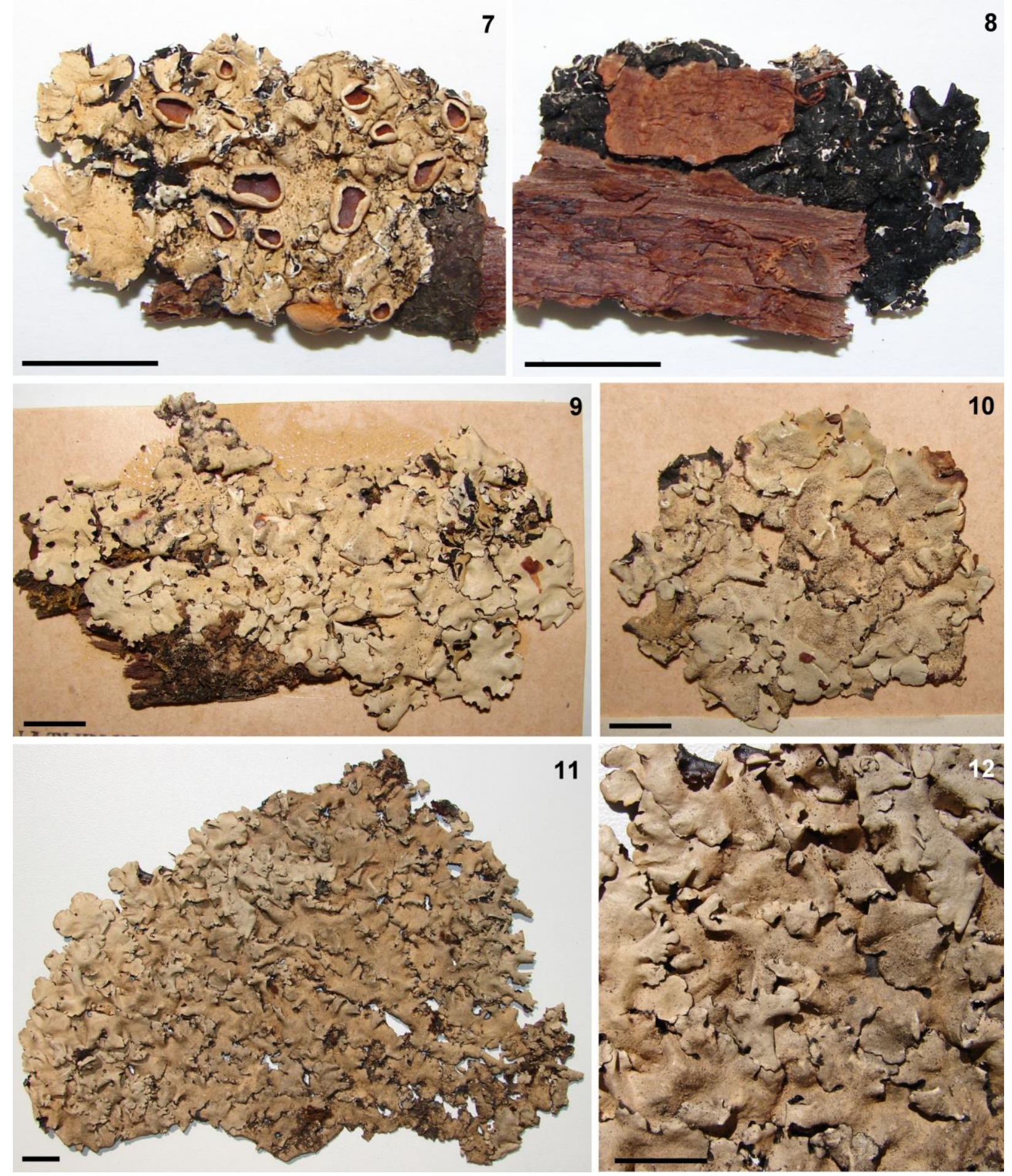

Figs 7-8 - Parmelinella mutata, 7 Lectotype (TUR). 8. Lower side of the lectotype. 9-10 Parmelinella nimandairana, 9 Holotype (TNS, fragment 1). 10 Holotype (TNS, fragment 2). 11-12 Parmelia nimandairana f. sublaevis. 11. Holotype (TNS). 12. Detail of the upper cortex. - Bars $=1$ $\mathrm{cm}$.

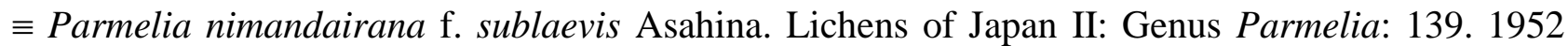
(holotype TNS!).

Thallus \pm laciniate, pale greenish gray in herbarium, up to $33.2 \mathrm{~cm}$ diam., subcoriaceous, corticolous. Lobes irregularly to anisotomic dichotomously branched, (0.8-) 1.4-7.0 (-9.0) mm wide, imbricate becoming crowded at the center, flat to subcanaliculate, adnate, \pm adpressed, with plane to often involute, subrotund apices, margins flat to involute, smooth to crenate, entire, rarely 
sublobulate, axils oval or irregular. Upper surface mostly smooth and continuous, occasionally subrugose, with few to dense transversal or irregular cracks in older parts. Adventitious lobules sparse, occasionally spreading from lobes margins on older parts, $0.2-1.3 \times 0.1-0.6 \mathrm{~mm}$, usually simple to occasionally irregularly branched, \pm plane, rotund to subtruncate, eciliate, underside concolorous with the lower marginal zone. Maculae absent, only scars left by eroded isidia. Cilia black, apices simple, 0.05-0.60 $(-0.70) \times$ ca. $0.03 \mathrm{~mm}$, frequent but usually common at the lobes axils often on a thick marginal black line, scarce or absent at younger parts. Soredia and pustules absent. Isidia granular to short cylindrical, often monilliform, $0.05-0.30(-0.50) \times$ ca. $0.05(-0.10)$ $\mathrm{mm}$, smooth, simple to sparsely branched, erect, firm but fragile, concolorous with the upper cortex but often with brownish apices, eciliate, laminal. Medulla white, without pigment spots. Lower surface black, rarelly dark brown spotted, shiny, smooth to rugose or venate, often slightly papillate, moderately rhizinate. Marginal zone brown, attenuate, 2.0-5.0 mm wide, shiny, smooth to rugose, sometimes slightly papillate. Rhizines dark brown to black, simple to partially furcate or \pm dichotomously branched, $0.10-0.50(-0.80) \times 0.03-0.05 \mathrm{~mm}$, frequent to abundant, evenly distributed. Apothecia rare, sparse, substipiate, $0.8-3.5 \mathrm{~mm}$ wide, isidiate, smooth to \pm rugose, eciliate. Ascospores absent (hymenia damaged or immature, without asci). Pycnidia rare, scarce, laminal, with black ostioles, conidia bacilliform to weakly bifusiform (4.0-) 5.0-7.0 $\times$ ca. $1 \mu \mathrm{m}$.

Spot tests - upper cortex $\mathrm{K}+$ yellow, UV-; medulla $\mathrm{K}+$ yellow $\rightarrow$ bright red, $\mathrm{C}-$, $\mathrm{KC}-, \mathrm{P}+$ yellow, UV-. Substances present: cortical atranorin, medullary salazinic acid (see also Hale 1976).

Additional material examined - India orientalis, Hinterindien, Assam, Khasya Hills, leg. Griffith s.n. (M); Japan, Prov. Kii, Mt. Koya, on rocks, elevation about 800 m, 17/18-XII-1960, leg. S. Kurokawa 60237 (M); India, Kerala, Idukki district, Thenmallay, Toi Estate área, near Munnar, along roadside, alt. ca. $1800 \mathrm{~m}$, on rock, 26-III-1985, leg. D.D. Awasthi \& R. Tewari 85307 (M); idem, Hinterindien, Assam, Khasya Hills, leg. Griffith s.n. (M, 2 exsicates); idem, Darjeeling District, Kalimpong, on way to Musong, alt. ca. 5500ft., over Stones, III-1967, leg. D.D. Awasthi \& M.R. Agarwal 67324 (M); idem, Kalimpong division, on way to Munsong from Kalimpong alt. 4500-5000 ft., on bark of Cryptomeria japonica, 10-III-1967, leg. D.D. Awasthi \& M.R. Agarwal 67260 (M); Nepal, Himalaya, Pengarah, Steilflächen an Blöcken, 09-X-1962, leg. J. Poelt s/n. (M); Philippines, Montain Prov. Baguio ad Pines Hotel ad corticem Pini, VII-1964, leg. M.E. Hale 26757 (M); Kenya, Steilabfall links vom Naro Moru Track, Mt. Kenya, Nyeri District, Central Province, corticol am Stamm von Erica arborea, 37¹4'00' E/ 0 09'50'’S, 3560 m, 16-VIII-1995, leg. A. Frisch 95/K14150 Duplette (M).

Notes - The lectotype (W!) and isolectotype (TNS!) specimens of Parmelia nimandairana are morphologically similar to the type specimen of Parmelinella wallichiana, but the laciniae are narrower, usually 1.5-4.0 mm wide. The cilia are quite common at the axils which have a thick marginal black line. The lower cortex in P. nimandairana is black with brown margins. The laminal isidia are very short, simple and generally have a darkened apical portion and \pm monilliform shape, and all the materials have short axillary cilia and sparse adventitious lobules.

Remarkably, this material is very similar to collections of $P$. wallichiana from Brazil. It is also somewhat similar to $P$. cinerascens, except for the laciniae differing (their shape and branching pattern) and the cilia are much longer and more dense.

$P$. nimandairana as appears very similar to $P$. wallichiana but with narrower lobes, a more uniformly black lower cortex and what appear to be monilliform, shorter, simple isidia. Like $P$. wallichiana it has a coriaceous thallus with \pm canaliculate lobes with involute apices in contrast to the flat thalli of $P$. cinerascens. The marginal cilia are also larger and more common in $P$. wallichiana and P. nimandairana.

The type material of Parmelia nimandairana f. sublaevis (TNS!) is a $15 \mathrm{~cm}$ wide specimen similar to $P$. nimandairana, however the laciniae are somewhat broader [(1.5-) $2.5-7.5 \mathrm{~mm}]$ and a closer to that observed in the type material of Parmelinella wallichiana. The type of Parmelia nimandairana f. sublaevis also has cilia with the same aspect on a thick black marginal line in the axils. The isidia are rather sparse, and although being a well developed thallus, it lacks apothecia and pycnidia. The upper cortex is even more fissured (especially in older parts) than the other 
specimens studied, sometimes resembling a "rimelioid" thallus where cracks are numerous. Parmelia nimandairana f. sublaevis exhibits no cortical maculae and the thallus is usually plane and smooth, with short, somewhat monilliform isidia. This specimen has some \pm dichotomously or irregularly branched rhizines mixed with the simple ones.

Both the types of Parmelia nimandairana and $P$. nimandairana $\mathrm{f}$. sublaevis have a predominantly black lower cortex while $P$. wallichiana has a variable black/brown lower cortex. Although no ascospores were found here due the poor condition of the apothecia hymenia, Hale (1976) cited ascospores 14.0-18.0 × 8.0-10.0 $\mu \mathrm{m}$ for both Parmelinella wallichiana and Parmelia nimandairana, as he accepted the later as a synonym of the first.

Parmelinella salacinifera (Hale) Marcelli \& Benatti, comb. nov.

Fig 13 Mycobank MB810474

Basyonym - Parmelia salacinifera Hale. Contributions from the United States National herbarium 36: 157. 1964.

Holotype - United States of America, Sanford, Seminole County, Florida, leg. S. Rapp, III1925 (US!, isotype FLAS n.v.).

$\equiv$ Pseudoparmelia salacinifera (Hale) Hale. Phytologia 29: 191. 1974.

$\equiv$ Canoparmelia salacinifera (Hale) Elix \& Hale Mycotaxon 27: 279. 1986.

Thallus lobed, greenish gray becoming dusky greenish gray in herbarium, up to $14.0 \mathrm{~cm}$ diam., subcoriaceous to submembranaceous, corticolous. Lobes irregularly ramified, 1.5-5.0 (-8.0) $\mathrm{mm}$ wide, contiguous to imbricate, closely adnate and adpressed to sometimes partially ascending and canaliculate, with rotund or subrotund apices, the margins entire, partly crenate, \pm plane to involute, upper surface continuous and smooth in the distal parts turning cracked and rugose in the older parts. Maculae absent to weak, irregular, laminal, mainly on distal parts. Cilia absent or sparse, randomly appearing at the margins but often in the lobes axils, simple and very short (usually $\leq 0.3 \mathrm{~mm}$, rarely reaching $0.5 \mathrm{~mm}$ long). Lacinules absent, small adventitious lobules absent to common at random parts of the margins, short, $0.2-2.0 \times 0.1-1.5 \mathrm{~mm}$, plane, simple, apices rotund to truncate, lower side concolorous with the lower marginal zone. Soredia and pustules absent. Isidia granular to short cylindrical, $0.05-0.30(-0.60) \times$ ca. $0.05 \mathrm{~mm}$, smooth, simple or slightly branched, sometimes partially clustered, erect, firm to caducous, concolorous with the upper cortex or with brown or black apices, eciliate, laminal. Medulla white, without $\mathrm{K}+$ pigments. Lower surface brown, sometimes with darker spots, shiny, smooth to slightly rugose, rarely papillate. Marginal zone brown, not distinct from the center, shiny to opaque, smooth to slightly rugose or veined, usually naked but sometimes sparsely rhizinate approaching the center. Rhizines brown, the same color as the lower cortex, simple to rarely irregularly branched, acute, 0.10-0.60 (-0.80) $\times$ ca. $0.05 \mathrm{~mm}$, few to frequent, \pm evenly distributed. Apothecia concave, sessile, imperforate, amphithecium eventually isidiate, the margins folded when mature, $0.5-6.0 \mathrm{~mm}$ diam, ascospores (not found in the holotype, hymenia without asci), ellipsoid, 12.0-16.0 (-20.0) $\times$ 7.0-9.0 $(-11.0) \mu \mathrm{m}$, epispore ca. $1 \mu \mathrm{m}$. Pycnidia sparse to common, laminal to mainly submarginal, with black ostioles. Conidia bacilliform to weakly bifusiform, 5.0-7.0 $\times$ ca. $1.0 \mu \mathrm{m}$.

Spot tests - cortex $\mathrm{K}+$ yellow, $\mathrm{UV}-$; medulla $\mathrm{K}+$ yellow $\rightarrow$ dark red, $\mathrm{C}-, \mathrm{KC}-, \mathrm{P}+$ yellow, UV-. TLC: cortical atranorin and chloroatranorin; medullary salazinic acid and consalazinic acid.

Known distribution - Southeastern United States, Mexico, Central America and Caribbean islands, Colombia, Venezuela, Brazil and Thailand (Hale \& Kurokawa 1964, Hale 1976, Breuss 2001); the latter provides the only non-American record.

Additional material examined - USA, Florida State, Seminole County, Sanford, Melonville on Quercus, leg. S. Rapp s.n., VI-1939 (FLAS); idem, Polk City, Polk County, on cypress trunks in Cypres Head, near Polk City, leg. J.B. McFarlin s.n., 16-VII-1931 (FLAS); idem, Lake County, Tavares, on palmetto near Railroad d, leg. S. Rapp s.n., 18-I-1921 (FLAS); idem, Bradford County, along Co. Rd. 227, $1.0 \mathrm{mi} \mathrm{SW}$ of Co. Rd. $225,29^{\circ} 53^{\prime} \mathrm{N}, 82^{\circ} 10^{\prime} \mathrm{W}$, Taxodium swamp, leg. R.C. Harris 35847, 3-XII-1994 (FLAS); idem, Marion County, Ocala national Forest, NE of Mill Dam 


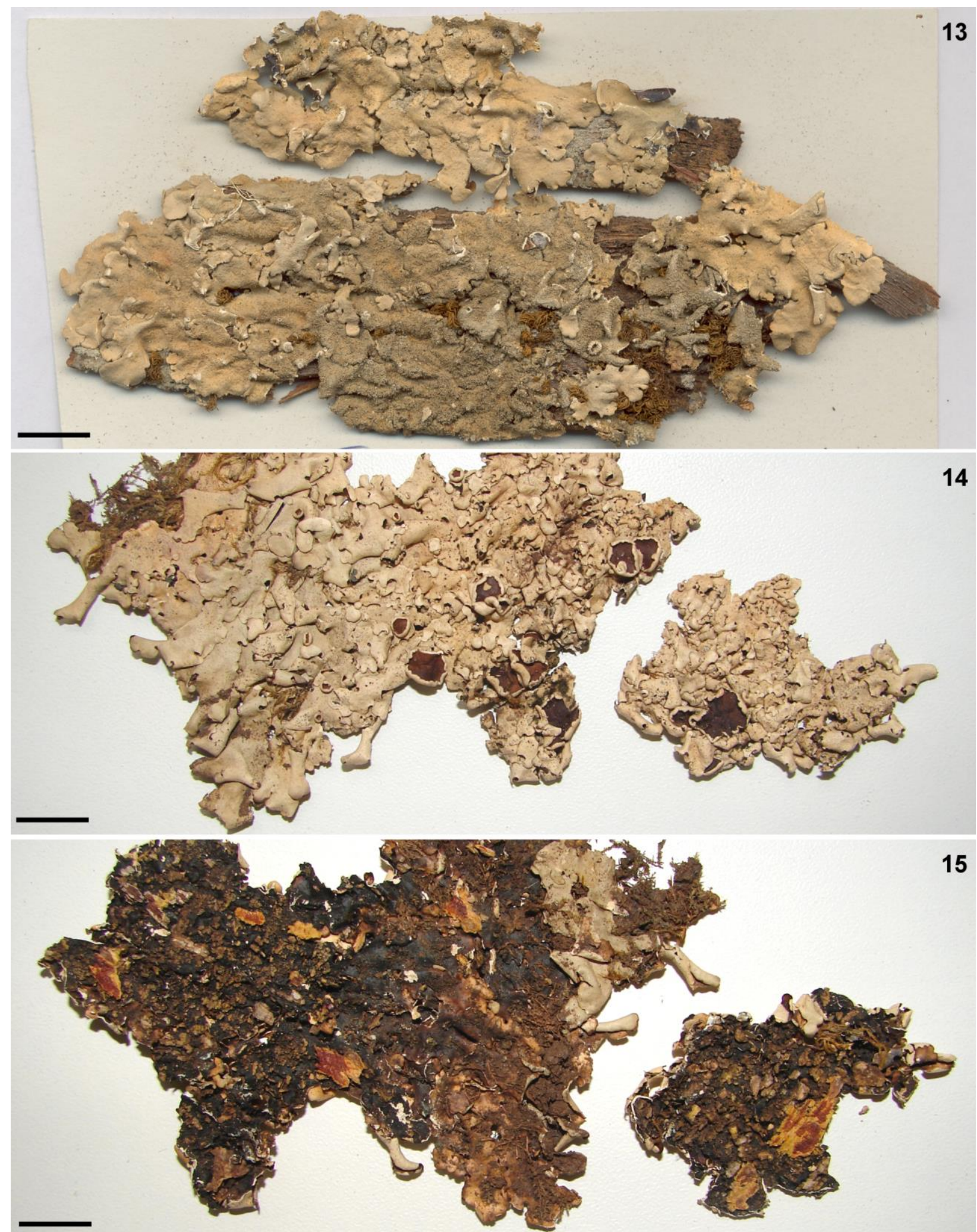

Figs 13 - Parmelinella salacinifera 13 Holotype (US). 14-15 Parmelinella simplicior. 14 Holotype (US). 15 Detail of the lower cortex. - Bars $=1 \mathrm{~cm}$.

lake, hardwood scrub successive to sand pine, leg. R. C. Harris 21066, 8-XII-1987 (FLAS); idem, Leon County, open oak woods W of U.S. Hwy. 319, 3.5 mi of Wakulla County Line, Apalachicola national Forest, leg. R. C. Harris 25376, 7-V-1990 (FLAS); idem, Gilchrist County, Waccassa Flats, along Co. Rd. 232 ca. $3 \mathrm{mi}$ E of US 129, ca. $8 \mathrm{mi} \mathrm{N}$ of Trenton, $29^{\circ} 44^{\prime} \mathrm{N}, 82^{\circ} 48^{\prime} \mathrm{W}$, shrubby cypress dome with Cyrilla and Ilex, leg. R.C. Harris 31715, 5-XII-1993 (FLAS); idem, Hernando 
County, Withlacoochee State Forest, Richloam Wildlife Management Area, N. Grade Rd at Lion Rd. $0.7 \mathrm{mi}$ E of Fla. Hwy 471, $16.5 \mathrm{mi} \mathrm{N}$ of US 98, $28^{\circ} 29^{\prime} \mathrm{N}, 82^{\circ} 04^{\prime} \mathrm{W}$, small cypress dome, on Taxodium, leg. R. C. Harris 29799, 4-XII-1992 (FLAS); idem, Clay County, Gold head Branch State Park, along Florida Trail near park entrance, $29^{\circ} 51^{\prime} \mathrm{N}, 81^{\circ} 58^{\prime} \mathrm{W}$, longleaf pine-turkey oak scrub, on dead Quercus, leg. R. C. Harris 29105, 28-XI-1992 (FLAS); idem, Volusia County, South Tomoka Wildlife management Area, along Co. Rd. 4118 (Pioneer Trail) at jet of St. Rd. 44, $29^{\circ} 02^{\prime} \mathrm{N}, 81^{\circ} 08^{\prime} \mathrm{W}$, open young Taxodium swamp, leg. R.C. Harris 37321, 6-I-1996 (FLAS); Brazil, São Paulo State, Municipality of Itirapina, João Batista de Arruda Penitentiary, cerrado vegetation, on a tree trunk, leg. P. Jungbluth \& F.R. Martins 511, 16-VIII-2003 (SP); idem, on thin branch, leg. P. Jungbluth \& F.R. Martins 520, 16-VIII-2003 (SP); idem, on thick cork tree, leg. P. Jungbluth \& F.R. Martins 543b, 550, 16-VIII-2003 (SP); Municipality of São Paulo, Parque Estadual da Cantareira, on tree trunk on roadside to Mairiporã, leg. M.P. Marcelli, O. Yano, A. Rezende \& F.M. Coppolla 11584, 25-VI-1991 (SP); Minas Gerais State, Municipality of Catas Altas, Serra do Caraça, Parque Natural do Caraça, on stone wall next to the gate of the courtyard in front of the hotel, leg. M.P.Marcelli \& C.H. Ribeiro 31955, 09-IX-1997 (SP); idem, Santa Catarina State, Blumenau, Parque Botânico de Cerro Baú, alt. 50 m, on tree trunk, low wood at the edge of country Road, leg. M. Fleig 6177 04-II-1994 (ICN); idem, Rio Grande do Sul State, Guaíba, Matzenbacher farm, alt. $200 \mathrm{~m}$, on thin twigs, top of the Hill, leg. M. Fleig 7210, 15-I-1997 (ICN); idem, Encruzilhada do Sul, Mina Velha 3rd District, Verro da Árvore farm, on bush, leg. M Fleig 7097, 09-IX-1995 (ICN); idem, Torres, Lajeadinho, on Eucalyptus sp., leg. H. Osorio \& M. Fleig T41c, 09-IX-1995 (ICN); idem, Porto Alegre, Morro Santana, alt. 300 m, top of the hill, edge of the wood, on tree, leg. M. Fleig \& Medeiros Filho PA/245, 17-I-1990 (ICN); idem, Morrinhos do Sul, Perdida, deforested area, grazing fields, leg. M. Fleig 4948, 30-III-1993 (ICN).

Notes - The holotype of Parmelinella salacinifera (US!) consists of two well preserved fragments. They exhibit no axillary cilia, just like the holotype of Parmelinella simplicior. Maculae are hard to discern due the state of the specimens. After examining the type and other specimens that are identified as $C$. salacinifera, I concluded that the axillary cilia found on many specimens have a small variation such as being sparse to absent, much like Parmelinella simplicior.

It was found that many specimens do exhibit very small, randomly distributed, marginal cilia. However, some specimens like the type, have no cilia, while others have randomly distributed cilia that vary in density from one specimen to another, as well as on different lobes of the same specimen. These cilia are usually brown or light brown, and they may be hard to see on many specimens because they are very small and sparse. There are thalli without cilia, thalli with sparse and irregularly distributed cilia, and a few which are more ciliate. We were even able to find a thallus with a few furcate cilia amid the sparse, simple ones.

The holotype of $P$. wallichiana (FH!) has much larger lobes and also larger ascospores (Benatti 2012) Further, the lower cortex of $P$. wallichiana is variable, and irregularly blackened. Cilia are more common and readily observed in $P$. wallichiana than in $P$. salacinifera.

No ascospores were found at the type specimen of $P$. salacinifera, as the apothecia on the holotype lack mature asci. Mature ascospores are apparently difficult to find, as Hale cited them only once (Hale 1976) based on a few additional specimens examined. The species was described (Hale \& Kurokawa 1974) without mature ascospores. Moore (1968) also mentioned that apothecia were uncommon.

The North American population is commonly pruinose and occasionally irregular maculae can sometimes be observed (similar to those normally seem in Canoparmelia species) particularly on younger lobes. This appears to be easily seen on the specimens with narrower lobes, but is was difficult to confirm whether this was related to the presence or abscence of axillary cilia; most specimens from North America appear to be completely eciliate while most specimens from South America appear to be ciliate. However, no other characteristics appears to differ significantly. A molecular investigation would be necessary to determine if two distinct taxa are involved or not, but it depends on finding many fresh samples from a very large area, ranging from North to South America. 
Basyonym: Parmelia simplicior Hale. The Bryologist 75: 99. 1972.

Holotype: India, Western Ghats, Panchgani, leg. D.D. Awasthi 4056, 15-VI-1959 (US!, isotype Awasthi herbarium n.v.)

$\equiv$ Parmelina simplicior (Hale) Hale. Phytologia 28: 483. 1974.

$\equiv$ Pseudoparmelia simplicior (Hale) Krog \& Swinscow. Lichenologist 19: 99. 1987.

Thallus sublinearly laciniate, dusky gray in herbarium, up to $11.5 \mathrm{~cm}$ diam., coriaceous, corticolous. Lobes irregularly branched, 1.1-4.3 (-5.4) mm wide, imbricate to often crowded, adnate, \pm adpressed, with flat to slightly involute, rotund to \pm rotund apices, margins flat to slightly involute, \pm sinuous to subirregular, entire to partially incised, often sublacinulate, axils oval to irregular. Upper surface subrugose to rugose (especially at densely pycnidiate parts) with some occasional transverse cracks at random parts. Adventitious lobules or lacinules often spreading from lobes margins, $0.3-1.2 \times 0.2-0.6 \mathrm{~mm}$, simple or furcate, plane, \pm rotund to truncate, eciliate, underside concolorous with the lower marginal zone. Maculae absent. Cilia absent to sparse, black, apices simple to irregularly branched, $0.05-0.35(-0.50) \times$ ca. $0.05 \mathrm{~mm}$, usually at the lobes axils and occasionally at random parts. Soredia, pustules and isidia absent. Medulla entirely white, without pigmented spots. Lower surface variable, from almost entirely black with rare, random dark brown spots to mottled, ranging from black to pale brown or with different shades of brown, shiny, smooth to occasionally subrugose, rarely papillate, weakly to moderately rhizinate, with bare parts. Marginal zone black to rarely dark or pale brown, sometimes barely distinct from the center, $\leq 1.0 \mathrm{~mm}$ wide, shiny, smooth, nude to slightly papillate at the transition to the center. Rhizines black, simple or occasionally irregularly branched, $0.20-0.80 \times 0.03-0.05(-0.10) \mathrm{mm}$, sparse to \pm frequent, evenly distributed. Apothecia common, \pm concave, partially fissured and distorted when old, sessile to substipitate, margin smooth to subrugose, eciliate, amphithecium smooth, sometimes pycnidiate, 0.4-7.8 $\mathrm{mm}$ wide; disc pale brown to dark brown, imperforate; epruinose; ascospores (hard to find, often only immature asci present) ellipsoid, (10.0-) 12.0-17.5 × 7.5-10.0 $\mu \mathrm{m}$, epispore 1.0-2.0 $\mu \mathrm{m}$. Pycnidia abundant, immersed, with black ostioles, conidia bacilliform to weakly or distinctly bifusiform, (4.0-) 5.0-6.5 × $0.5 \mu \mathrm{m}$.

Spot tests - upper cortex $\mathrm{K}+$ yellow, $\mathrm{UV}-$; medulla $\mathrm{K}+$ yellow $\rightarrow$ dark red, $\mathrm{C}-, \mathrm{KC}-, \mathrm{P}+$ yellow, UV-. Substances present: atranorin, salazinic acid (according to a label left on the type material; see also Hale 1972, 1976, Swinscow \& Krog 1988, Divakar \& Upreti 2005).

Known distribution - Africa: Ethiopia, Uganda (Swinscow \& Krog 1988). Asia: China (Chen et al. 2003), India (Divakar et al. 2000, Divakar \& Upreti 2005, Hale 1972, 1976) and Thailand (Moon et al. 2000 apud Chen et al. 2003). Accordingly to the ascospores measurements, it is possible that a similar, undescribed species has been confused with $P$. simplicior (see below).

Additional material examined - India, Maharashtra, felled tree at bridge, Ambenali, on Road to Pratapgad, M.E. Hale 40090, 2-XI-1973 (US); idem, trees in open park, elev. about 500 m, Pahala Fort, M.E. Hale 43972, 16-I-1975 (US); idem, evergreen rain forest, elev. about $1200 \mathrm{~m}$, Mahabaleshwar region, M.E. Hale 40007, 01-XI-1973 (US); idem, Pacnhgani, on Eugenia sp., leg. Rev. E. Blatter s.n., XII-1927 (US); idem, Vaijanatt, corticolous, leg. S.R. Panchagawi 961, 2-X1957 (US); idem, Kanta, Lonavala, corticolous, leg. S.R. Panchagawi 89, 18-VIII-1957 (US); idem, Western Ghats, Panhala Fort, Kolhapur district, on Pongamia glabra, elev. app. 3500 ft., leg. P.G. Patwardhan \& A.V. Prabhu 74.1010, 74.1032 (M).

Notes - The holotype material (US!) is a specimen in good condition; it is labeled as "isotype", but accordingly to Hale $(1972,1976)$ it was the material designated as the holotype. It does not have a uniformly colored lower cortex, instead it is quite variable, with mixed shades ranging from black to pale brown. It exhibits most of the variations observed in the specimens examined but no other specimens seen has all of them. The holotype does not appear to have any cilia like several other specimens examined, but has many adventitious, marginal lacinulae. The apothecia have many asci, but mostly immature ones with juvenile ascospores, but those measured 
were in agreement with the larger ones cited on literature (Divakar \& Upreti 2005, Swinscow \& Krog 1988), rather than the smaller ones cited by Hale $(1972,1976)$ and Chen et al. (2003). The presence of absence of cilia is similar to that observed in $P$. salacinifera (see above).

Accordingly to Hale (1972), P.simplicior has a black lower cortex with brown margins, very small ascospores $(5-7 \times 3-4 \mu \mathrm{m})$, and very short conidia $(2-3 \mu \mathrm{m}$ long), but this could not be confirmed. Instead I observed larger ascospores $(10-17.5 \times 7.5-10 \mu \mathrm{m})$ and conidia up to $7 \mu \mathrm{m}$ long similar to those cited by Swinscow \& Krog (1988) and Divakar \& Upreti (2005) in the type collection and additional material examined.

Chen et al. (2003) mentioned ascospores 5-7 $\times 4 \mu \mathrm{m}$, closer to Hale (1972), and different from those of Swinscow \& Krog (1988) and Divakar \& Upreti (2005). None of the specimens examined have small ascospores, indicating that there may be a similar, undescribed species which occurs in eastern Asia.

While most descriptions record sparse rhizines, Swinscow \& Krog (1988) described them as being dense, and sometimes white tipped at the apices. The specimens studied showed rhizines of variable density, but never really dense, and usually totally black. Swinscow \& Krog (1988) mentioned African specimens with large lobes $(3-15 \mathrm{~mm}$ ) but otherwise similar to those from southern Asia.

Parmelinella simplicior differs from $P$. chozoubae by its broader lobes (commonly twice the width), usually simple rhizines, and variable color of the lower cortex. Accordingly to Chen et al. (2003), the absence of medullary pigmentosin A and secalonic acid A in P. chozoubae is a further difference, while Divakar \& Upreti (2005) report the presence of zeorin in P. chozoubae.

The short, axillary cilia are restricted to part of the axils in some specimens, and a few specimens appear to have very few or none at all (like the holotype and Hale 40007 and 40090).

However, there are no other significant differences between the eciliate specimens and those that are moderately or sparsely ciliate.

Parmelinella versiformis (Krempelhuber) Marcelli. Acta Botanica Brasilica 7: 56. 1993. Figs 16-17 Mycobank 459297

Basionym: Parmelia versiformis Krempelhuber. Flora 61: 464. 1878.

Lectotype (chosen here): Argentina, leg. Lorentz \& Hyeronimus s.n., 1872-74 (M!; isolectotypes G!, PC n.v.).

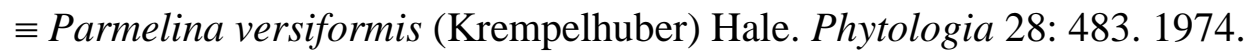

Thallus lobate, (pale) dusky gray in herbarium, up to $7.5 \mathrm{~cm}$ diam., submembranaceous, corticicolous. Lobes irregularly branched, $1.0-4.2 \mathrm{~mm}$ wide, imbricate to rarely crowded in older parts, adnate, adpressed, with \pm flat, rotund to subrotund apices, margins flat to slightly involute, subcrenate or subirregular, entire to incised, not lacinulate, axils oval to irregular. Upper surface subrugose to rugose, with irregular cracks mostly in older parts. Lobules absent, including marginal adventitious ones. Maculae absent. Cilia black, apices simple, $0.05-0.15 \times$ ca. $0.03 \mathrm{~mm}$, usually sparse in the lobes axils and random other parts. Soredia, pustules and isidia absent. Medulla entirely white, without pigmented spots (although it can be stained by oxidized and hydrolyzed salazinic acid). Lower surface pale to dark brown, shiny, \pm smooth to rugose or venate, occasionally papillate, moderately rhizinate, with some random bare parts. Marginal zone pale to dark brown and indistinct from the center, shiny, smooth to rugose or venate, weakly papillate, partially rhizinate. Rhizines pale to dark brown, simple, 0.10-0.40 $\times 0.03-0.05 \mathrm{~mm}$, frequent, evenly distributed. Apothecia common, concave to fissured and folded when mature, substipitate, margin smooth to subrugose, eciliate, amphithecium rugose, 0.5-7.8 $\mathrm{mm}$ wide; disc brown, imperforate, epruinose; ascospores ellipsoid, 17.0-25.0 (-26.0) $\times 10.0-17.0 \mu \mathrm{m}$, epispore 1.0-3.0 $\mu \mathrm{m}$. Pycnidia common, immersed, with black ostioles, conidia bacilliform to weakly bifusiform, 5.0-6.5 $\times 0.5$ $\mu \mathrm{m}$.

Spot tests: upper cortex $\mathrm{K}+$ yellow, $\mathrm{UV}-$; medulla $\mathrm{K}+$ yellow $\rightarrow$ bright red, $\mathrm{C}-, \mathrm{KC}-, \mathrm{P}+$ yellow, UV-. Substances present: cortical atranorin, medullary salazinic acid (see also Hale 1976, 
also agreeing with a label from $\mathrm{H}$. Krog with the lectotype).

Distribution - This distribution once included the three synonyms now combined under Parmelinella mutata (Parmelia mutata, P. catharinesis and P. wetsteinii), which all belong to a single different taxon (Parmelinella mutata, see previously). Many materials need yet to be carefully examined for confirmation of belonging either to $P$. versiformis or P. mutata; confirmed specimens are cited in P. mutata distribution. South America. Argentina (Krempelhuber 1878, Hale 1976), Brazil (Hale 1976, Marcelli 1993, Ribeiro 1998, Eliasaro 2001, Eliasaro \& Adler 2000, Jungbluth 2006) and Venezuela (Lopez-Figueiras 1986).

Notes - Krempelhuber (1878) cited a brown lower cortex ("subtus fuscescens") for this species, a feature here confirmed in the lectotype and isolectotype specimens. His ascospores measurements (17-19 $\times 11-13 \mu \mathrm{m})$ are also in accord with those observed, although not encompassing the full range of variation (up to $26 \mu \mathrm{m}$ long and $16 \mu \mathrm{m}$ wide). After examining the type materials of P.versiformis and its synonyms, I noticed that the synonyms in fact all belong to a single similar taxon, with a distinct black lower cortex, that all belong now to Parmelinella mutata (see above).

The lectotype (M!) is composed of three fragments, partially deteriorated and somewhat damaged, all of similar size. However, the two smaller fragments are very lacinulate, have narrower crenate lobes and both are isidiate, and belong to a different species, possibly Parmelinella salacinifera, rather than to $P$. versiformis.

The isolectotype (G!) is composed of two small, partially damaged fragments, between 3 and $3.5 \mathrm{~mm}$ wide. It has some mature apothecia. Like the lectotype above, the lower cortex is brown overall, mostly pale brown. There are many pycnidia, but conidia were not found.

Parmelinella wallichiana (Taylor) Elix \& Hale. Mycotaxon 29: 242. 1987.

Fig 18 Mycobank 130580

Basionym - Parmelia wallichiana Taylor. London Journal of Botany 6: 176. 1847.

Holotype - Nepal, leg. Wallich s.n. (FH-Taylor!).

三 Parmelina wallichiana (Taylor) Hale. Phytologia 32: 483.1974.

三Pseudoparmelia wallichiana (Taylor) Krog \& Swinscow. Lichenologist 19: 424. 1987.

Thallus lobed, pale dusky gray (partially darkened at isidiate parts) in the herbarium, up to $18.8 \mathrm{~cm}$ diam., subcoriaceous, corticolous. Lobes irregularly to subdichotomously branched in part, (3.0-) 5.0-10.0 (-16.0) mm wide, contiguous to imbricate becoming \pm crowded at the center, plane, adnate and adpressed, with flat, rotund to subrotund apices (these partially irregular when at central parts where part of the lobes are more often sublaciniate), margins flat to involute, smooth to crenate or partially irregular, entire to incised, occasionally sublacinulate, axils obtuse, oval or irregular. Upper surface mostly smooth and continuous, partially irregularly cracked at older parts. Adventitious lobules or lacinules sparse, occasionally spreading from lobe margins (particularly on older parts), $0.5-3.0 \times 0.3-1.0 \mathrm{~mm}$, simple, furcate or irregularly branched, short, plane, often truncate but becoming rounder as they assume aspect of lobes, eciliate, underside concolorous with the lower marginal zone. Maculae absent, only scars left by eroded isidia. Cilia black, apices simple, base often thickening from the marginal line (not truly bulbate), $0.1-0.50 \times$ ca. $0.03-0.05$ $\mathrm{mm}$, absent at younger parts, sparse to common in the lobes axils, often joining side by side on a thick, marginal, axilary black line. Soredia and pustules absent. Isidia laminal, frequent or sparse, granular to branched cylindrical, straight to twisted, $0.05-0.50 \times$ ca. $0.05-0.15 \mathrm{~mm}$, erect, firm to partially caducous at some parts, concolorous with the upper cortex or with brownish apices, eciliate. Medulla white, without pigmented spots (but can be partially stained by the oxidized or hydrolysed salazinic acid in random parts). Lower surface variably brown (at distal parts) to black (at proximal parts), partially dark brown spotted, shiny, smooth to subrugose, partially papillate, scarcely to moderately rhizinate. Marginal zone brown to pale brown and attenuate ranging from $2.0 \mathrm{~mm}$ to several $\mathrm{cm}$ wide, shiny, smooth, nude to slightly papillate. Rhizines brown (sometimes darker than the lower cortex), simple, $0.10-1.00 \times 0.05-0.15 \mathrm{~mm}$, scarce near the margins becoming frequent at the center, evenly distributed. Apothecia usually concave, occasionally 


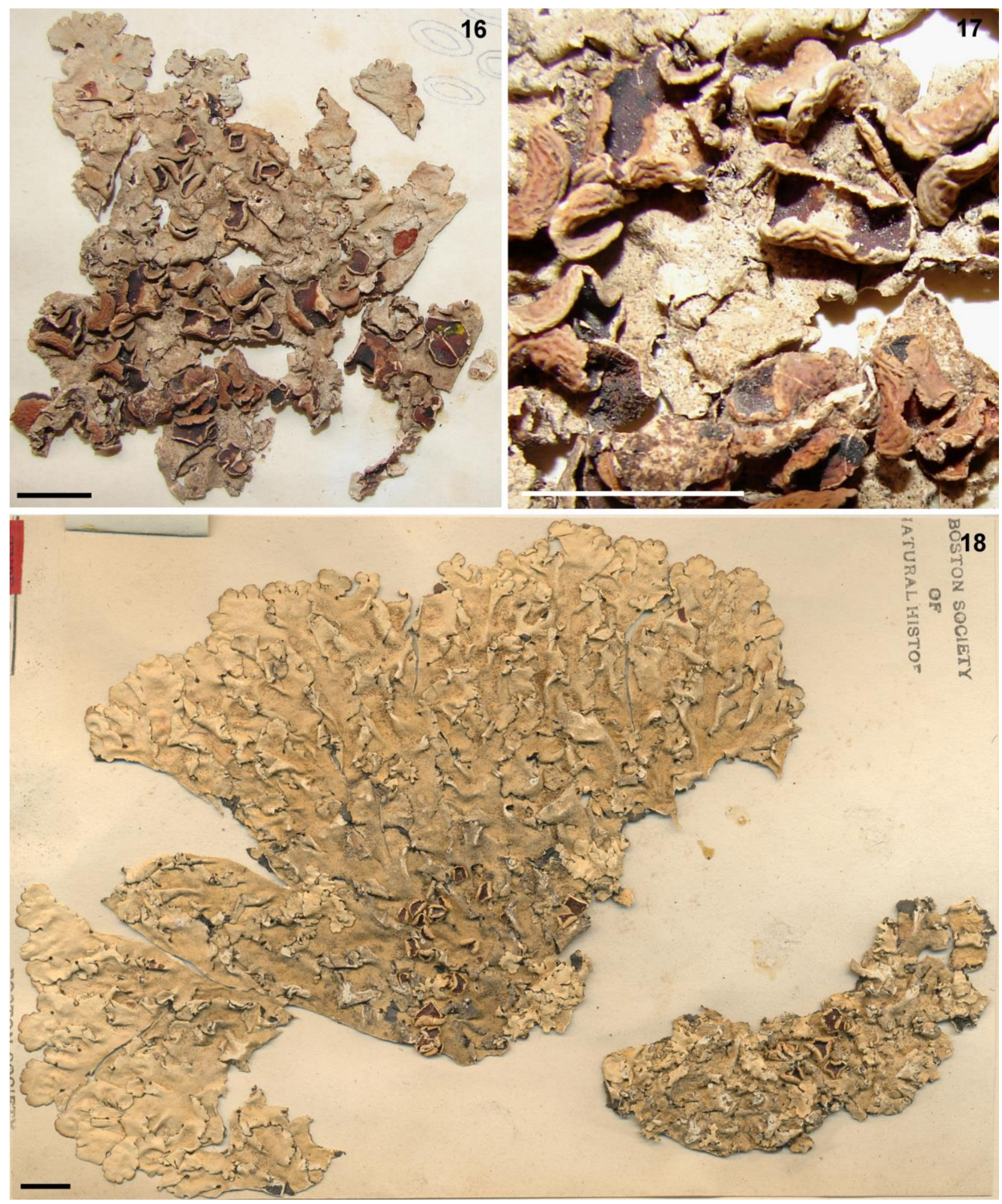

Figs 16-17 - Parmelinella versiformis, 18 - Parmelinella wallichiana. 16. Holotype (M). 17. Detail of the upper cortex and apothecia. 18. Holotype $(\mathrm{FH}) .-$ Bars $=1 \mathrm{~cm}$.

\pm plane or cupuliform, becoming fissured and folded as they develop, adnate to sessile, $1.0-7.0 \mathrm{~mm}$ wide, laminal to submarginal but mainly restricted to the central parts of the thalli, margins initially smooth, soon becoming fissured and \pm crenate due the formation of the isidia, eciliate, amphythecium smooth, sometimes becoming slightly rugose, less isidiate than the margins or without any isidia even at mature stages. Disc concave, brown, epruinose, imperforate. Ascospores usually ellipsoid, occasionally almost subglobose, $15.0-20.0 \times(8.0-) 10.0-12.5 \mu \mathrm{m}$, epispore 1.0 $2.0 \mu \mathrm{m}$. Pycnidia absent (several parasitic fungi found only). 
Spot tests - upper cortex $\mathrm{K}+$ yellow, $\mathrm{UV}-$; medulla $\mathrm{K}+$ yellow $\rightarrow$ bright red, $\mathrm{C}-, \mathrm{KC}-, \mathrm{P}+$ yellow, UV-. Substances present: cortical atranorin, medullary salazinic acid (see also Hale 1976; Louwhoff \& Elix 2002 also cited several substances presented as traces in specimens from Papua New Guinea, including protocetraric acid and some unknown pigments).

Distribution - Hale (1976) reported that Parmelina (Parmelinella) wallichiana was the most widespread and commonly found species of Parmelina in the old world, mainly Africa (Angola, Ethiopia, Guinea, Ivory Coast, Kenya, Madagascar, Rhodesia, Swaziland, Uganda, Union of South Africa, Tanzania) and Asia (China, India, Indonesia, Japan, Nepal, Papua New Guinea, Philippines, Taiwan, Thailand). Today, this distribution also includes citations for Australia, and Brazil in South America (Canêz 2005, Divakar \& Upreti 2005, Eliasaro \& Adler 2000, Elix 1994, Hale 1976, Jungbluth 2006, Kurokawa \& Lai 2001, Swinscow \& Krog 1988, Taylor 1847, Zahlbruckner 1909).

Notes - Elix (1994) mentioned simple and sparse cylindrical isidia, and conidia 5-6 $1 \mu \mathrm{m}$ (but not their shape). Only Elix (1994) and Divakar \& Upreti (2005) mentioned saxicolous specimens.

Chen et al. (2003) gave a description very similar to Hale (1976), but they confirmed the presence of other chemical medullary substances (pigmentosin A and eumitrin derivatives) in their material. Divakar \& Upreti (2005) mentioned a wide range in thalli size, lobe configuration, apothecia frequency and ascospore size. Most notably, these authors reported that the specimens found in southern India had narrower lobes, were more frequently found fertile, and have much smaller ascospores $(8-10 \times 4-5 \mu \mathrm{m})$, while specimens from Sikkim in the Himalayas, have larger apothecia often reaching $15 \mathrm{~mm}$ in diameter, and much larger spores, 15-20 $\times 9-14 \mu \mathrm{m}$, the latter in accord with those seen in the type material. The material from southern India may well belong to P. cinerascens (Benatti 2012), given the black lower cortex and ascospores sizes.

Specimens of Parmelinella (Pseudoparmelia) wallichiana cited by Swinscow \& Krog (1988) from eastern Africa have small ascospores, 6-10 $(-12) \times 4-6 \mu \mathrm{m}$, except for a single specimen from Ethiopia $(12-16 \times 8-10 \mu \mathrm{m})$, all with weakly bifusiform conidia, 5-6 $\mu \mathrm{m}$ long. The ascospore sizes might indicate that more than one taxon is involved, possibly even $P$. cinerascens. The authors suspected that $P$. wallichiana may be the isidiate counterpart of $P$. simplicior.

Louwhoff \& Elix (2002) recorded specimens of $P$. wallichiana from Papua New Guinea with features similar to those reported by Hale (1976) and Kurokawa \& Lai (2001). These authors also mentioned traces of other substances including protocetraric acid and unknown pigments. The only different features noted were the partially dichotomously branched rhizines but the lower cortex was black with dark brown margins. The conidia of their specimens were found to be bacilliform to weakly bifusiform, like those seen by Swinscow \& Krog (1988).

Kurokawa \& Lai (2001) reported this species as having a black to dark tan lower cortex (similar to the type specimen), dense isidia in central parts of the thallus, and rare apothecia up to $15 \mathrm{~mm}$ in diameter, with ascospores $14-18 \times 8-10 \mu \mathrm{m}$ (also close to the type specimen).

\section{Acknowledgements}

The author wishes to thank the curators of ASSAM (K. P. Singh), B (R. Vogt), BM (R. Huxley), FH (D. Pfister), FLAS (K. Perkins), G (P. Clerc), M (A. Beck), NY (B. Thiers), S (A. Anderberg), TNS (Y. Ohmura), US (R. Russell), and UPS (S. Ekman), for loans or access to type specimens and additional material, Michaela Schmull (FH) for help with data about P. mutata and $P$. wallichiana type materials, Harrie J. Sipman and John A. Elix for the English review, comments, and suggestions, and the reviewers for critical revision of the manuscript.

\section{References}

Benatti MN. 2011 - A simple clearing technique to aid in the recognition of cilia and rhizinae structure in the Parmeliaceae. Opuscula Philolichenum 9, 21-25. 
Benatti MN. 2012a - A review of the genus Bulbothrix Hale: the species with medullary salazinic acid lacking vegetative propagules. MycoKeys 5, 1-30.

Benatti MN. 2012b - Canoparmelia cinerascens belongs in the genus Parmelinella (Parmeliaceae, lichenized Ascomycota). Opuscula Philolichenum 11, 26-30.

Benatti MN. 2013 - A review of the genus Bulbothrix Hale: the isidiate, sorediate and pustulate species with medullary salazinic acid. Mycosphere 4, 1-30.

Benatti MN, Marcelli MP. 2007 - Worldwide key for Parmelinella Elix \& Hale (Parmeliaceae, lichenized Ascomycota). Segunda Reunião Brasileira de Estudos Liquenológicos, 62-68.

Canêz LS. 2005 - A família Parmeliaceae na localidade de Fazenda da Estrela, municipio de Vacaria, Rio Grande do Sul, Brasil. Mastership dissertation, Instituto de Botânica, São Paulo.

Chen J-B, Wang S-L, Elix JA. 2003 - Parmeliaceae (Ascomycota) lichens in China's mainland I. The genera Canomaculina, Parmelina, Parmelinella and Parmelinopsis. Mycotaxon 86, $19-29$.

Crespo A, Kauff F, Divakar PK, del Prado R, Pérez-Ortega S, de Paz, GA, Ferencova Z., Blanco O, Roca-Valiente B, Núñez-Zapata J, Cubas P, Argüello A, Elix JA, Esslinger TL, Hawksworth D L, Millanes AM, Molina MC, Wedin M, Ahti T, Aptroot A, Barreno E, Bungartz F, Calvelo S, Candan M, Cole MJ, Ertz D, Goffinet B, Lindblom L, Lücking R, Lutzoni F, Mattsson J-E, Messuti MI, Miadlikowska J, Piercey-Normore MD, Rico VJ, Sipman HJM., Schmitt I, Spribille T, Thell A, Thor G, Upreti DK, Lumbsch HT. 2010 Phylogenetic generic classification of parmelioid lichens (Parmeliaceae, Ascomycota) based on molecular, morphological and chemical evidence. Taxon 59, 1735-1753.

Divakar PK, Upreti DK. 2005 -. Parmelioid Lichens in India - a Revisionary Study. Bishen Singh Mahendra Pal Singh, India.

Divakar PK., Upreti DK, Chatterjee, S. 2000. A key to species of the lichen genus Parmelia sensu lato in the Indian subcontinent. Geophytology 30, 1-16.

Divakar PK, Crespo A, Blanco O, Lumbsch HT. 2006 - Phylogenetic significance of morphological characters in the tropical Hypotrachyna clade of parmelioid lichens (Parmeliaceae, Ascomycota). Molecular Phylogenetics and Evolution 40: 448-458.

Eliasaro S. - 2001. Estudio taxonomico y floristico sobre las Parmeliaceae sensu stricto (Ascomycota liquenizados) del Segundo Planalto del Estado de Paraná, Brasil. Tese de Doutorado. Facultad de Ciencias Exactas y Naturales, Universidad de Buenos Aires.

Eliasaro S, Adler MT. 2000 - Espécies de Canomaculina, Myelochroa, Parmelinella e Parmelinopsis (Parmeliaceae, Ascomycotina liquenizados) do Segundo Planalto do Estado do Paraná, Brasil. Acta Botanica Brasilica 14, 141-149.

Elix JA. 1993 - Progress in the generic delimitation of Parmelia sensu lato lichens (Ascomycotina: Parmeliaceae) and a synoptic key to the Parmeliaceae. The Bryologist 96, 359-383.

Elix JA. 1994 - Parmelinella. In: Orchard, A.E. \& Grgurinovic, C. (eds.) 1994. Flora of Australia. Volume 55. Lichens - Lecanorales 2, Parmeliaceae. Australian Government Publishing Service, Canberra.

Elix JA 2003 - The lichen genus Paraparmelia, a synonym of Xanthoparmelia (Ascomycota, Parmeliaceae). Mycotaxon 87, 395-403.

Elix JA, Hale ME. 1987 - Canomaculina, Myelochroa, Parmelinella, Parmelinopsis and Parmotremopsis, five new genera in the Parmeliaceae (lichenized Ascomycotina). Mycotaxon 29, 233-244.

Elix JA, Johnston J, Verdon D. 1986 - Canoparmelia, Paraparmelia and Relicinopsis, three new genera in the Parmeliaceae (lichenized Ascomycotina). Mycotaxon 27, 271-282.

Hale ME. 1972 - Four new species of Parmelia (Lichenes) from India and the Philippines. The Bryologist 75, 97-101.

Hale ME. 1976 - A monograph of the lichen genus Parmelina Hale (Parmeliaceae). Smithsonian Contributions to Botany 33, 1-60.

Jungbluth P. 2006 - A família Parmeliaceae (fungos liquenizados) em fragmentos de cerrados do 
Estado de São Paulo. Mastership dissertation. Instituto de Botânica, São Paulo.

Krempelhuber A. 1878 - Lichenes collecti in republica Argentina a Doctoribus Lorentz et Hieronymus determinati et descripti. Flora (Regensburg) 61, 433-439, 461-464, 476-480, 492-496, 516-523.

Kurokawa S. 1985 - Studies on Australian and Tasmanian species of Parmelia (2). Bulletin of the National Science Museum, Tokyo, Series B, 11, 77-90

Kurokawa S, Lai, M-j. 2001 - Parmelioid lichen genera and species in Taiwan. Mycotaxon 77, 225-284.

Lopez-Figueiras M. 1986 - Censo de macroliquenes venezolanos de los estados Falcon, Lara, Merida, Tachira y Trujillo. Facultad de Farmacia, Universidad de Los Andes, Merida.

Louwhoff SHJJ, Elix JA. 2002 - Hypotrachyna (Parmeliaceae) and Allied Genera in Papua New Guinea. Bibliotheca Lichenologica, 81, J. Cramer, Berlin, Stuttgart.

Lynge B. 1914 - Die Flechten der ersten Regnellschen Expedition. Die Gattungen Pseudoparmelia gen. nov. und Parmelia Ach. Arkiv för Botanik 13, 1-172.

Marcelli MP. 1993 - Pequenas Parmelia s.l. (líquens: Ascomycotina) ciliadas dos cerrados brasileiros. Acta Botanica Brasilica 7, 25-70.

Marcelli MP. 2004 - Checklist of lichens and lichenicolous fungi of Brazil. Version 1: June 2004. http://www.biologie.uni-hamburg.de/checklists/brazil_l.htm. (Acessed March 2007)

Marcelli M, Ribeiro CH. 2002 - Twenty-one new species of Parmeliaceae (lichenized fungi) from southeastern Brazil. Mitteilungen aus dem Institut für Allgemeine Botanik in Hamburg 30$32,125-155$.

Müller Argoviensis J. 1891 - Lichenes Catharinenses a cl. E. Ule in Brasilia prov. Santa Catharina lecti. Hedwigia 30, 235-243.

Nash TH, Gries C, Elix JA. 1995 - A revision of the lichen genus Xanthoparmelia in South America. Bibliotheca Lichenologica, 56, J. Cramer, Berlin, Stuttgart.

Pooprang T, Boonpragob K, Elix JA. 1999 - New species and new records in the lichen family Parmeliaceae (Ascomycotina) from Thailand. Mycotaxon 71, 111-127.

Ribeiro CH. 1998 - A família Parmeliaceae (Ascomycota liquenizados) em Regiões montanhosas dos estados de Minas Gerais, Rio de Janeiro e São Paulo. Dissertação de Mestrado, Universidade de São Paulo, São Paulo.

Singh KP. 1980 - A new species of Parmelina from India. The Bryologist 83, 533-534.

Singh KP, Sinha GP. 1993 - Two new species of Parmelina from India. Nordic Journal of Botany 13, 463-466.

Singh KP, Sinha GP. 2010 - Indian Lichens: an annotated Checklist. Botanical Survey of India, Kolkata.

Sipman HJM, Elix JA, Nash TH. 2009 - Hypotrachyna (Parmeliaceae, Lichenized Fungi). Flora Neotropica Monograph 104. The New York Botanical Garden Press, Bronx.

Swinscow TDV, Krog H. 1988 - Macrolichens of East Africa. British Museum of Natural History, London.

Taylor T. 1847 - New Lichens, principally from the Herbarium of Sir William J. Hooker. London Journal of Botany 6, 148-197.

Vainio EA. 1890 - Etude sur la classification et la morphologie des lichens du Brésil, I. Acta Societatis pro Fauna et Flora Fennica 7, V-XXIX, 1-247.

Zahlbruckner A. 1909 - Lichenes (Flechten). In: V. Schiffner (ed.), Ergebnisse der botanischen Expedition der kaiserlichen Akademie der Wissenschaften nach Südbrasilien, 1901, 2. Band. 83, 85-211. 